\title{
Implementation of Tax Planning Strategy in Effort Income Tax Saving on PT Bank Perkreditan Rakyat Batam
}

\author{
Robin (BC202120113), Ita Kristiana (BC211120115) \\ DOI: 10.29322/IJSRP.12.01.2022.p12158 \\ http://dx.doi.org/10.29322/IJSRP.12.01.2022.p12158
}

\begin{abstract}
This study focuses on the tax administration strategies of PT.BPR Batam in terms of reducing income tax and saving other income taxes. This study used the qualitative description to explain the strategy by revealing the condition of financial gain and loss. Report of this fact supported by the company. They are then processed into data that can be examined to draw a conclusion. PT BPR Batam participated in the commercial services set up by Bank Indonesia and enjoyed special tax treatment. This study found that tax planning will optimize after-tax profit by using a different depreciation method. PT BPR Batam used the declining balance method in previous years, however, the researcher used the straight-line depreciation method and can demonstrate that it saves Rp taxes. $30,657,431$. Additionally, the researchers collectively used the gross method to calculate tax Article 21 to allow workers to save PPh Rp 21 in taxes. 8,219,600. Tax planning for PT BPR Batam could save taxes in 2020 Rp. 8,059,049.
\end{abstract}

Keywords- Tax saving, income tax, tax planning, Batam.

\section{INTRODUCTION}

Taxes for the govt. are a supply of income wont to finance state expenditures, each routine expenditure, and development expenditures. except for companies, taxes are prices or expenses that may cut back earnings. If the profits are obtained by large companies automatically the income tax paid to the state treasury is also large. Based on this phenomenon, the company, in this case, the financial manager, tries to be able to lawful tax savings or reductions (still within the framework of tax provisions). Companies can take various ways to minimize the tax burden while still in the context of complying with tax provisions using tax planning.

Tax planning is the initial stage to hold out a scientific analysis of assorted tax treatments to attain the fulfillment of minimum tax obligations. In the current globalization and the level of intense competition, a manager of a company or business entity in carrying out their company's tax planning is required to master the situation at hand. Both the situation in terms of internal and external, so that tax planning can be carried out accurately and thoroughly on transactions that have an impact on taxation.

PT BPR Batam as one of the Local Banks in the Riau Islands is a financial institution that has a significant increase in assets every year. The income/profit earned by BPR Batam automatically becomes a tax subject as well as a tax object for a country. Profit is a crucial side for banks that are used for the future to take care of business continuity. In order that a bank can invariably try and increase profits sustainably. The larger the profit earned by a bank, the greater the tax borne by the bank. As a result, the bank has to pay a large amount of tax owed. PT BPR Batam pays income tax every year which always increases, this can be minimized through tax planning with several methods that refer to the Income Tax Law no. 36 of 2008.

The purpose of this study was to seek out the outline of the commercial and fiscal financial statements and to work out the impact of the appliance of tax planning on the income tax paid by PT BPR Batam in 2020.

\section{LITERATURE REVIEW}

\section{II.1 Definition of Tax}

The definition of tax in step with Prof. DR. Rochmat Soemitro, SH defined that taxes are people's contributions to the countrysupported regulation (maybe forced) whilst now no longer receiving reciprocal services, which can be at once proven and accustomed finance well-known contests. (Mardiasmo, 2009:1). Meanwhile, Prof. DR. PJA Andriani defines tax, Tax is a contribution to the 
country (which may be forced) owed with the aid of using the ones which are obligated to pay it in step with the regulations without acquiring overall performance back, that may be at once proven, and what is useful is to finance contests - well-known charges concerning country duties. to arrange government (Andriani, 1989:2). Article 1 \#1 of Law Number 6 of 1983 as ultimately amended with the aid of using Law Number sixteen of 2009 regarding General Provisions and Tax Procedures (UU KUP) states that: Tax is a taxpayer tax to the country this is owned with the aid of using a person or a coercive frame primarily based totally at the regulation with the aid of using now no longer getting an immediate imbalance and getting used for the desires of the country for the finest prosperity of the people (UU KUP, 2009).

\section{II.2 Tax collection system}

In tax collection, there are many tax collection systems, namely: official accounting system, self-assessment system, and holding system.

\section{Official investigation system}

tax collection system that allows the tax team to know the number of taxes owed annually according to the provisions of the applicable tax laws. Under this system, the initiative and activity of collusion and tax collection are entirely in the hands of the tax apparatus.

The success or failure of the implementation of tax collection thus depends strongly on the tax apparatus (the tax apparatus plays the dominant role).

\section{Self-Assessment Scheme}

tax collection scheme that allows taxpayers to view the number of taxes owed each year in accordance with the provisions of applicable tax laws.

In this system, the initiative and activity in arranging and carrying out tax collection lie in the hands of the taxpayer. Taxpayers are assumed to be able to calculate taxes, be able to perceive applicable tax rules, be very honest and understand the importance of paying taxes.

\section{Withholding tax system}

A system of tax collection that authorizes the third party to determine the amount of tax owed by the taxpayer under the provisions of the applicable tax laws. and collect taxes, deposits, and accounts through accessible tax facilities. The success or failure of the assembly process depends largely on the commissioned third party.

\section{II.3 Barriers to Collection of Taxes}

Apart from awareness as citizens, most people do not fulfill the obligation to pay taxes. In this case, resistance to taxes arises. Resistance to taxes can be divided into:

\section{Passive Resistance}

Passive resistance within the type of obstacles that complicate collection and incorporates a shut relationship with the economic structure. People are reluctant (passively) to pay taxes, which can be caused, among others:

a. Intellectual and moral development of society.

b. A tax system that (perhaps) is difficult for the public to understand.

c. The control system cannot be carried out or implemented properly.

\section{Active Resistance}

Active resistance includes all efforts and actions aimed directly at tax authorities to avoid taxes. Forms include:

a. Tax evasion, an attempt to reduce the tax burden by not breaking the law.

b. Tax evasion, an attempt to reduce the tax burden by breaking the law.

\section{II.4 Income Tax}

With reference to Law No. 36 of 2008, income tax may be a mandatory tax on capital gains, whether income is received or earned by entirely different individuals or entities, domestically and/or abroad owed throughout the tax year. Subject to income tax is anything that has the potential to generate income and is a target subject to income tax. Indonesian Income Tax Law regulates the levying of income tax on taxable persons with respect to income received or earned within the tax year. Taxable subjects are subject to financial income tax when they derive or receive income in accordance with applicable laws and regulations (Income Tax Law No. 36 of 2008 ).

Purpose of Income Tax Based on Article 4(1) of Law 36 of 2008 on Income Tax, the purpose of income tax means any additional economic capacity that a payer receives or obtains both from Indonesia and outside of Indonesia, namely and in any form, for consumption or can be used to increase the wealth of the taxpayer concerned. 
Tax Administration is an attempt to generate tax savings that can be legally implemented through Tax Administration. Note, however, that the legality of tax administration depends on the instrument used. Legality will surely be glorified only with a judicial decision. Lumbantoruan in Sandy (2008:6) argues that tax management could be a means to adequately meet tax obligations, but the amount of taxes paid can be reduced as little as possible for profit and liquidity in order to preserve expected benefits and liquidity.

The purpose of tax administration can be achieved through the functions of tax administration, namely:

1. Tax planning

2. Compliance with tax obligations (tax implementation)

3. Tax control

Tax planning

According to Suandy (2008:6), tax planning is openness in tax administration. In this phase, tax rule compilation and analysis are applied to select the types of tax-saving measures to be implemented.

Zain (2008:67) reveals that tax planning could be a structuring action relating to the potential tax consequences, the stress of that is on dominant each dealing that has tax consequences. The goal is however these controls will contour the quantity of tax to be transferred to the government, through what's referred to as tax avoidance and not tax evasion.

\section{Stages in Making Tax Planning}

Suandy (2011:13) states that for tax planning to achieve success as expected, the arrange ought to be administrated through varied sequences of the subsequent stages:

\section{Analyze existing info (Database)}

the primary stage of tax planning is to investigate the various parts of tax concerned in an exceedingly project and calculate as accurately as potential the tax burden that's borne. this will solely be done by considering every component of the tax, each severally and in total, that should be developed because of the best tax planning.

It is also important to take into account the possible income from a project and other non-tax expenses that may occur. For this reason, a tax manager must pay attention to both internal and external factors, namely: relevant facts, tax facts, other non-tax factors.

\section{Create One or More Models of Tax Amount Plans}

Selection of the form of operating transactions or international relations. In almost all international tax systems, at least two countries are pre-determined. From a tax point of view, the planning process cannot be outside the stages of selecting the most profitable transactions, operations, and relationships.

3. analysis of Tax planning

Tax planning is an idea that may be a little a part of the complete strategic planning of the company, thus it's necessary to judge to ascertain however so much the results of the implementation of a tax planning on the tax burden, variations in gross profit, and expenses excluding taxes on varied different plans.

\section{Finding Weaknesses so purification The Tax plan}

to mention that the results of a tax planning are smart or not, of course, it should be evaluated through various plans made. Action changes (up-to-date planning) must be distributed even if extra prices are required or the likelihood of success is extremely small. As long as the tax savings are still large, the plan must be carried out, because after all the losses incurred are minimal. So, it will be very helpful in making a plan is accompanied by a description or estimate of how many chances of success and how much potential profit will be obtained if successful or potential loss if there is a failure.

\section{Updating the Tax plan}

despite the fact that a tax plan has been enforced and therefore the project has been running, it's still necessary to require under consideration any changes that occur, each from the law and its implementation (the country wherever the activity is carried out) that may have an effect on the elements of a treaty.

\section{RESEARCH METHODOLOGY}

The research method used in this research is descriptive with a qualitative approach. According to Arikunto (2006:12), qualitative research means that in its activities the researcher will not use numbers in collecting data and in providing interpretations of the results.

Descriptive analysis analyzes solely the amount of description, particularly analyzing and presenting facts consistently so it will be easier to grasp and conclude. knowledge assortment techniques that researchers do are interviews, observations, and documentation. Furthermore, the tactic of knowledge analysis dispensed is 
1. Analyze existing information (Database).

Analyze all components that exist in the company and analyze the sources of income obtained by the company as well as analyze the costs that may be deducted and which may not be deducted by the Income Tax Law No. 36 of 2008 Article 6 paragraph (1) and Article $9(1)$.

2. Make one or more models of possible tax magnitude plans.

3. Create a tax planning model related to the depreciation expense used by PT BPR Batam and the depreciation method allowed in the tax laws and regulations. Planning for income tax paid to company employees through methods permitted by tax laws.

4. Evaluating the Implementation of Tax Planning.

5. Evaluating differences in the income statement of PT BPR Batam before and after-tax planning in the commercial and fiscal financial statements.

6. Look for weaknesses and then revise the tax plan.

7. Updating the Tax Plan Make adjustments in the implementation of tax planning (tax planning) so that the tax implementation remains based on the applicable laws and regulations.

\section{FINDINGS AND DISCUSSIONS}

\section{Batam BPR Financial Report}

PT BPR (People's Credit Bank) as a trading company with income is required to keep accounts as per General Provisions and Tax Procedures Law No. 28, 2007. Bank Indonesia provides RPGs with guidelines for establishing SAK ETAP. The process of compiling guidelines for writing BPR accounts involving stakeholders and going through due process includes public hearings and limited hearings. Re PSAK No. 27 The bank's annual accounts consist of a balance sheet, a profit and loss account, and a cash flow statement. The main financial statements generated from the accounting process are the company's balance sheet and income statement. Financial statements are the end result of the accounting process. When calculating taxes for PT BPR Batam, reference is made to the company's profit and loss account.

\section{Report on Depreciation of Fixed Assets of PT BPR Batam}

In general, companies in their business activities carry out tax deductions due to cash disbursements, both for purchasing goods, paying for labor, and other services used in operational activities. Cash disbursements for this purpose provide more benefits than one period. For tax purposes, this kind of treatment of expenses can create problems in determining income tax.

Depreciation is the allocation of the amount of an asset that can be depreciated over its estimated useful life (PSAK 17). The depreciation needs to be done because the benefits provided and the value of the asset is decreasing. The reduction in asset value is charged in stages (Suandy 2011: 30).

The following is a report on the results of depreciation of property and equipment of PT BPR Batam in 2020 using the straight-line method.

Data Analysis and Interpretation Analyzing Existing Information and Databases.

1. Income Analysis on the Profit and Loss Statement of PT BPR Batam

By the financial statements of PT BPR Batam that the net income from the company's business circulation comes from interest income of Rp. 5,110,889,403. Based on the income statement of the company's income, the following are the company's revenue account posts, namely:

\section{a. Interest income}

PT BPR Batam in running a business earns operational income, one of which is comes from interest on loans. Operating income on interest is obtained from Interest income from other banks Rp. 166,495.020, Nonbank interest income of Rp. 4,124,250,450, Provision of Interest Income Rp. 676,575,581, KYD fines Rp. 140,325,352, Deposit penalty income of Rp. 3,423,000. 
Non-operational income is income that is not related to routine operational activities company. The non-operating income of PT BPR Batam is Rp. 5,489,450.

2. Expense Analysis on the Profit and Loss Statement of PT BPR Batam

Based on the results of the company's income statement, the following is an explanation of the expense account items listed in the income statement, namely:

a. Interest expense

PT BPR Batam in the form of bank business, apart from providing credit, also functions as a commercial bank that serves the needs of the community as a place to save and serve the needs of customers in terms of investment. The following is a breakdown of the company's operating interest expense: Interest expense to other banks Rp.24,335,682 Interest expense to non-bank third parties Rp. 195.723,356 Interest Expense on Deposits Rp. 411,168,783 Interest Expense on loans received Rp. 4,200,000 Other interest expense Rp. $1,110,976,358$.

b. Premium Expense

BPJS insurance premiums are Rp. 42,467,000. This insurance premium expense is intended for employees who are paid by the company. By the Income Tax Law, Article 6 paragraph 1 concerning costs that may be deducted from gross income.

\section{Selection of Bookkeeping Method}

The basis of bookkeeping that can be used to provide true and complete information about the income of taxpayers to be able to conduct taxes fairly, correctly, and fairly by the economic capacity of the taxpayer, which is recognized by the Directorate General of Taxes (DGT) is the modified cash accrual basis. On an accrual basis, revenues and expenses are recorded and reported when rights and obligations arise, even though the money has not been received or paid. On a cash basis, income and expenses are recorded and reported when cash is received and disbursed.

\section{Shrinkage Method}

PT BPR Batam uses the straight-line depreciation method for non-building fixed assets. In depreciating non-building fixed assets, the depreciation rate used by the RB is not by the depreciation rate stipulated in Article 11 of LAW No. 36 concerning Income Tax. Almost all fixed assets owned by the company were depreciated by $12.5 \%$. The assets should be classified first based on the group and depreciated according to the predetermined rate. The author has calculated the depreciation of non-building fixed assets using the declining balance method in the table. From the results of these calculations, there is a difference of Rp. 20,777,963, of the depreciation, carried out by the BPR of Rp. 42,366,753 with fiscal depreciation calculated by the author of Rp. 63,144,716. With the adjustment of the depreciation rate, BPR can save an income tax burden of Rp. 20,777,963.

\section{Evaluating Tax Planning}

From the results of fiscal reconciliation before tax planning and after-tax planning, it is proven that the taxable profit planning of PT BPR Batam is Rp. 1,543,536,117. However, after effective tax planning, the company's taxable profit becomes Rp. 1,511,298,154. The smaller the taxable profit, the impact on the amount of tax payable. If previously the tax owed was Rp. 385,884,029 after optimal tax planning was carried out, the tax amount for PT BPR Batam would be Rp. 377. 824,029. The company can save tax as much as Rp.8.059,490.

\section{CONCLUSION}

Based on the results of the research that has been done, it can be concluded that:

1. Commercial financial reports and reports

In the fiscal finances of PT BPR Batam in 2020, several accounts should be reconciled with negative fiscal to reduce the income tax that must be paid by PT BPR Batam. PT BPR Batam as a corporate taxpayer in fulfilling tax obligations is still less efficient so that in the company's commercial financial statements there are still costs that should be able to reduce income that has not been recorded by the company.

2. Tax planning that can be done by PT BPR Batam includes:

a. Depreciation on the declining balance resulted in a larger depreciation expense of Rp.63,144,716 when compared to the straight-line method, which was Rp.42,366,753.

b. Other costs incurred by the BPR should be given a nominative list and attached to the Annual Tax Return so that for the following year other costs can be used as fiscal costs and the BPR can save tax of Rp. 11,460,000.

\section{Impact of tax planning}

Income from the financial statements of BPR Batam, there is a material difference between the income tax payable before tax planning and after-tax planning. Before planning the PPh tax that must be paid by PT BPR Batam is Rp. 385,884,029 and after-tax planning is Rp. 377,824,029. The company can save tax as much as Rp.8.059,490. 
From the results of the discussion, calculations, and conclusions of the research results above, several suggestions can be given to be used as consideration by PT BPR Batam in carrying out its operational activities:

1. PT BPR Batam should implement tax planning as a corporate strategy in saving income tax payments paid by the company.

2. PT BPR Batam should depreciate fixed assets for the following year the company uses the declining balance depreciation method. Using this method will result in

larger depreciation expense when compared to using the straight-line method.

3. PT BPR Batam may include promotional costs and director's cellular telephone costs as a deduction from income provided that a nominative list is included by taxation and is attached to the Annual Tax Return.

4. PT BPR Batam in carrying out its obligation to pay PPh 21 should use the gross-up method and provide tax benefits to its employees through this method.

\section{REFERENCES}

Arikunto, Suharsimi.(2006). Prosedur Penelitian :Suatu Pendekatan Praktek. Edisi Revisi VI.

Jakarta : PT. Rineka Cipta.

Desak Eva Indira Pratiwi.2012. Perencanaan pajak sebagai upaya legal untuk meminimalkan pajak penghasilan (Studi Kasus Pada KSU Griya Anyar Sari Boga). Skripsi (S1). Akuntansi. Fakultas Ekonomi. Universitas Brawijya. Malang

Lumbantoruan,Sophar.(2006).Akuntansi Pajak Edisi Revisi. Jakarta:PT Gramedia Widiasarana Indonesia

Mardiasmo.(2008). Perpajakan: edisi revisi 2008. Yongyakarta: Andi.

Muljono,Djoko.(2009). Akuntansi Pajak Lanjutan. Yogyakarta : CV. Andi Offset.

Peraturan Menteri Keuangan Nomor 251/ PMK.03/2009 tentang penghasilan atas Jasa Keuangan yang dilakukan oleh Badan Usaha yang berfungsi sebagai penyalur pinjaman dan/atau pembiayaan yang tidak dilakukan pemotongan pajak penghsilan pasal 23.

Suandi, Erly.(2008) . Perencanaan Pajak revisi. Jakarta: Salemba Empat

Undang-Undang Nomor 36 Tahun 2008. Tentang Pajak Penghasilan.

Undang-Undang Nomor 6 Tahun 1983 Tentang Ketentuan Umum dan Tata Cara

Zain, M. (2008), Manajemen Perpajakan. Jakarta: Salemba Empat 
First Author - Robin, robin_1025va@ hotmail.com.

\section{AUTHORS}

Second Author - Ita Kristiana, itachristianna@gmail.com

Correspondence Author - Robin, robin_1025va@hotmail.com, +628127030360. 